\title{
Pengaruh Asam Hialuronat-Space Peptide terhadap Karakteristik, Stabilitas Fisik Gel Amniotic Membran- Stemcell Metabolite Product
}

\author{
Rina Mutya Suzliana ${ }^{1}$, Tristiana Erawati ${ }^{1}$, Cita Rosita Sigit Prakoeswa ${ }^{2,3}$, Fedik Abdul Rantam ${ }^{4}$, Widji Soeratri ${ }^{1}{ }^{*}$ \\ ${ }^{1}$ Departemen Farmasetika, Fakultas Farmasi, Universitas Airlangga, Surabaya, Indonesia \\ ${ }^{2}$ Departemen Ilmu Penyakit Kulit dan Kelamin, RSUD Dr. Soetomo, Surabaya, Indonesia \\ ${ }^{3}$ Departemen Dermatology dan Venerology, Fakultas Kedokteran, Universitas Airlangga, Surabaya, Indonesia \\ ${ }^{4}$ Laboratorium Stem Cell, Institute Topical Diseases, Universitas Airlangga, Surabaya, Indonesia
}

*Corresponding author: widjisoeratri@yahoo.com

Submitted: 18 Januari 2020

Accepted: 18 Februari 2020

Published: 30 November 2020

\begin{abstract}
Background: Amniotic membrane stem cell metabolite products (AMSC-MP) is the kind of metabolite product obtained from isolated amniotic membranes and cultured in conditioned medium. AMSC-MP contains growth factors and cytokines with aging treatment benefits. Growth factors and cytokines have molecular size which is larger than $20 \mathrm{kDa}$ as AMSC-MP, thus, requires special formulations to deliver for used topical. The formulation of hyaluronic acid is used as combination with SPACE peptide functioning as an enhancer macromolecule for AMSC-MP gel to improve as antiaging activity. To ensure a preparation quality and stability, evaluation of physical characteristic and stability is needed. Objective: To evaluate the effect of added hyaluronic acid $(0 ; 0.01 ; 0.02 ; 0.04 \%)$ combined with SPACE peptide on the characteristics and stability of the AMSC-MP gel formulation. Methods: The physical characteristics of AMSC-MP freeze dried gel preparations with the addition of hyaluronic acid combined with SPACE peptide were evaluated by organoleptic test (colour, odor and texture), measuring the $\mathrm{pH}$ and deployment capacity. Physical stability testing was done by evaluating gel physical characterics during 28 days of storage. Results: All of the formulas generally showed good appearance. Specifically, the gel observed was transparent, had thick consistency and had smooth texture with specific odour. pH Value was around 5.37-5.26 and deployment capacity was approximately in $6.50-6.13$. All the formulas were stable during 28 days of storage. Conclusion: The combination of hyaluronic acid and SPACE peptide to the gel formula did not destroy the characteristic and physical stability of AMSC-MP gel on storage for 28 days.
\end{abstract}

Keywords: amniotic membrane stem cell metabolite products (AMSC-MP), hyaluronic acid (HA), SPACE peptide, physical characteristic, physical stability

\begin{abstract}
Abstrak
Pendahuluan: Amniotic membran stem cell metabolite product (AMSC-MP) merupakan metabolit produk yang diperoleh dari Amniotic membrane yang diisolasi dan dikultur yang kemudian ditumbuhkan dalam medium terkondisi. AMSC-MP mengandung banyak growth factor dan sitokin yang sangat berguna sebagai antiaging. Growth factor dan sitokin yang pada umumnya berukuran besar lebih dari 20 KDa menyebabkan AMSC-MP membutuhkan formulasi khusus untuk penggunaannya secara topikal. Pada penelitian ini digunakan asam hialuronat dikombinasi dengan SPACE peptide yang memiliki fungsi sebagai enhancer makromolekul untuk formulasi sediaan gel AMSC-MP sebagai antiaging. Untuk memastikan kualitas dan stabilitas suatu sediaan, maka perlu dilakukan uji karakteristik fisik dan uji stabilitas fisik sediaan tersebut. Tujuan: Mengevaluasi pengaruh penambahan asam hialuronat $(0 ; 0,01 ; 0,02 ; 0,04 \%)$ yang dikombinasi SPACE peptide terhadap karakteristik dan stabilitas dari formulasi sediaan gel AMSC-MP. Metode: Karakteristik fisik sediaan gel freeze dried AMSC-MP dengan penambahan asam hialuronat yang dikombinasi SPACE peptide dievaluasi dengan menggunakan parameter organoleptis (warna, bau, konsistensi dan tekstur), pengukuran $\mathrm{pH}$ dan kapasitas
\end{abstract}


penyebaran. Pengujian stabilitas fisik dievaluasi dengan pengukuran $\mathrm{pH}$ dan kapasitas penyebaran sediaan setelah penyimpanan selama 28 hari. Hasil: Hasil uji karakteristik dan stabilitas fisik sediaan gel AMSC-MP menunjukkan penampilan fisik yang baik, gel transparan dengan konsistensi kental, lembut dengan bau yang khas. Nilai pH sekitar 5,26 - 5,37 dan kapasitas penyebaran pada 6,13 - 6,50. Semua formula stabil selama 28 hari penyimpanan. Kesimpulan: Penambahan kombinasi asam hialuronat dan SPACE peptide pada formulasi tidak merusak karakteristik dan stabilitas fisik sediaan gel AMSC-MP pada penyimpanan selama 28 hari.

Kata kunci: amniotic membran stem cell metabolit produk (AMSC-MP), asam hialuronat (HA), SPACE peptide, karakteristik fisik, stabilitas fisik

\section{PENDAHULUAN}

Amniotic Membran Stem Cell Metabolite Product (AMSC-MP) merupakan produk metabolit stem cell yang kini sedang dikembangkan sebagai suatu bahan yang digunakan dalam terapi seluler, regeneratif dan peremajaan kulit (Insausti dkk., 2010). AMSC-MP mengandung growth factor dan dan sitokin yang diketahui dapat mempengaruhi biosintesis kolagen serta dapat meningkatkan proliferasi keratinosit epidermal dan fibroblast dermal (Meenakshi dkk., 2017). Namun dalam hal ini, growth factor dan sitokin yang terkandung di dalam AMSC-MP merupakan molekul hidrofilik yang berukuran lebih besar dari $20 \mathrm{kDa}$ sehingga memiliki penetrasi yang buruk. Molekul yang berukuran lebih besar dari $500 \mathrm{kDa}$ sulit untuk penetrasi melalui stratum corneum (Bos \& Meinardi, 2000). Pada penelitian sebelumnya (Pratiwi dkk, 2018), AMSC-MP secara klinis diaplikasikan menggunakan microneedle menunjukkan efek photoaging yang menjanjikan sebagai terapi peremajaan. Namun hal ini dianggap kurang menyenangkan karena penggunaan microneedle memiliki keterbatasan yaitu harus dengan bantuan tenaga ahli dan dapat menimbulkan eritema setelah penggunaan (Pratiwi dkk., 2018).

SPACE peptide dilaporkan sebagai suatu bahan yang potensial untuk meningkatkan penghantaran pada kulit. SPACE peptide telah dikembangkan sebagai peningkat penetrasi untuk makromolekul HA (MW 200-325kDa) (Chen dkk., 2013) dan (siRNA MW $13 \mathrm{kDa})$ (Mitragotri \& Hsu, 2011) (Chen dkk., 2014). SPACE peptide diketahui tidak mengubah barier lipid kulit namun bekerja dengan cara berinteraksi dengan protein kulit dan menginduksi perubahan pada struktur sekunder protein kulit dan menginduksi perubahan pada struktur sekunder protein kulit ( $\alpha$ heliks, $\beta$-sheet, turn dan acak) yang dievaluasi dengan analisis FTIR dan dikonfirmasi dengan in-silico docking (Kumar dkk., 2015).
Dalam penelitian lain, (Murphy dkk., 2017) penggunaan AMSC-MP dikombinasi dengan asam hialuronat (HA) dilaporkan dapat memperbaiki penyembuhan luka (wound healing). Kombinasi ini memungkinkan untuk pengembangan sebagai sediaan antiaging dengan pertimbangan bahwa HA yang diketahui memiliki kemampuan untuk meningkatkan kualitas kulit dengan cara mengembalikan matriks ektraseluler dan aktivasi fibroblast, seperti produksi kolagen dan elastin (Landau \& Steven, 2015). Selain itu, HA juga dapat berfungsi sebagai enhancer biomakromolekul yang mungkin dimediasi oleh kombinasi co-transport, peningkatan hidrasi kulit dan modifikasi sifat stratum korneum (Witting dkk., 2015).

Berdasarkan beberapa penelitian tersebut, AMSCMP diformulasi dalam bentuk sediaan gel antiaging dengan beberapa variasi konsentrasi HA yang dikombinasi dengan SPACE peptide untuk memperoleh formula dengan karakteristik yang baik dan stabil pada penyimpanan.

\section{BAHAN DAN METODE Bahan}

Bahan yang digunakan dalam penelitian ini memiliki kemurnian pharmaceutical grade, antara lain AMSC-MP (dikultur di Laboratorium Stem Cell dan Instalasi Pusat Biomaterial-Bank Jaringan RSUD Dr. Soetomo), SPACE peptide (diimpor dari PT. MedChem express), asam hialuronat (PT. Evonic Industries), basis gel Carbopol 940 (PT. Adimitra Prima).

Alat

pH Meter Schott glass mainz CG 842 dan alat uji daya sebar (Laboratorium Farmasetika Universitas Airlangga).

\section{Metode}

\section{Persiapan formulasi sediaan gel AMSC-MP HA}

Penelitian ini merupakan eksperimental laboratorium. Gel dibuat dengan menimbang terlebih dahulu semua bahan yang akan digunakan. Carbopol 940 sebagai basis gel dikembangkan menggunakan 10 
ml aquabidest. Masukkan bahan aktif AMSC-MP Freeze dry yang telah dilarutkan dengan menggunakan $1 \mathrm{ml}$ aquabidest. SPACE peptide dan HA yang telah disiapkan, dimasukkan ke dalam basis gel dan dicampur hingga homogen dengan menggunakan homogenizer Ultra Turrax High Shear Homogenizer dengan kecepatan 100 rpm selama 10 menit. Sediaan gel yang dibuat dilakukan replikasi sebanyak tiga kali. Dibuat lima formula dengan variasi konsentrasi HA yang berbeda dan dikombinasi dengan SPACE peptide. $F_{I}, F_{I I}, F_{I I I}, F_{I V}$ dan $F_{v}$. Sediaan gel yang dibuat dilakukan replikasi sebanyak tiga kali. Komposisi setiap formula dapat dilihat pada Tabel 1.

Tabel 1. Formula sediaan gel Amniotic Membrane Stem Cell Metabolite Product (AMSC-MP) dengan beberapa konsentrasi HA dengan kombinasi SPACE peptide $\left(\mathrm{F}_{\mathrm{I}}, \mathrm{F}_{\mathrm{II}}, \mathrm{F}_{\mathrm{III}}, \mathrm{F}_{\mathrm{IV}}\right.$ dan $\left.\mathrm{F}_{\mathrm{V}}\right)$

\begin{tabular}{ccccc}
\hline \multirow{2}{*}{ Formula } & \multicolumn{4}{c}{ Konsentrasi Bahan $(\%)(\mathrm{b} / \mathrm{b})$} \\
\cline { 2 - 5 } & AMSC-MP & SPACE peptide & HA & Basis gel \\
\hline $\mathrm{F}_{\mathrm{I}}$ & 0,08 & - & - & ad 100 \\
$\mathrm{~F}_{\mathrm{II}}$ & 0,08 & 0,016 & - & ad 100 \\
$\mathrm{~F}_{\mathrm{III}}$ & 0,08 & 0,016 & 0,01 & ad 100 \\
$\mathrm{~F}_{\mathrm{IV}}$ & 0,08 & 0,016 & 0,02 & ad 100 \\
$\mathrm{~F}_{\mathrm{V}}$ & 0,08 & 0,016 & 0,04 & ad 100 \\
\hline
\end{tabular}

\section{Evaluasi karakteristik sediaan gel AMSC-MP Uji organoleptik}

Uji organoleptik dilakukan dengan cara visual dengan mengamati secara langsung penampilan sediaan meliputi warna, bau, konsistensi dan tekstur dari gel yang dibuat.

Uji pH

Uji $\mathrm{pH}$ dilakukan dengan menimbang 1 gram sediaan dan diencerkan dengan $10 \mathrm{~mL}$ air bebas $\mathrm{CO} 2$ ke dalam beaker gelas lalu diaduk hingga merata. Larutan diukur $\mathrm{pH}$ nya dengan menggunakan $\mathrm{pH}$ meter. Pengukuran diulangi sebanyak tiga kali (Rosita dkk., 2010).

\section{Uji kapasitas penyebaran}

Evaluasi kapasitas penyebaran dilakukan dengan menimbang sediaan gel sebanyak $1 \mathrm{~g}$ dan diletakkan pada lempeng kaca berskala, kemudian ditutup dengan lempeng kaca yang lainnya dengan ukuran masingmasing yaitu $20 \mathrm{~cm} \mathrm{x} 17 \mathrm{~cm}$, tebal $5 \mathrm{~mm}$ dan berat 404,5 g. Selanjutnya di atas lempeng kaca tersebut ditambahkan beban yang secara teratur ditingkatkan beratnya. Setiap 3 menit, diukur diameter penyebaran sediaan dan dicatat. Beban ditingkatkan tiap 5 gram sampai diperoleh diameter penyebaran yang konstan pada 25 gram (Rosita dkk, 2010).

\section{Evaluasi stabilitas fisik sediaan}

Sediaan disimpan pada suhu kamar $25^{\circ} \mathrm{C} \pm 0,5^{\circ} \mathrm{C}$ selama 28 hari dan RH $70 \pm 2 \%$. Dilakukan evaluasi
$\mathrm{pH}$ dan kapasitas penyebaran pada hari ke-0, ke-14 dan ke-28.

\section{Analisis statistika}

Data yang diperoleh dalam penelitian diolah dengan analisis dengan metode statistik One Way Anova. Apabila hasil yang diperoleh $(\mathrm{P}<0,05)$ maka ada perbedaan bermakna antar formula dan dilanjutkan dengan uji Post Hoc Tukey HSD untuk mengetahui kelompok formula mana saja yang berbeda.

\section{HASIL DAN PEMBAHASAN}

\section{Karakterisasi sediaan gel AMSC-MP Hasil uji organoleptis}

Hasil uji organoleptis sediaan gel AMSC-MP pada masing-masing formula diperoleh konsistensi yang cenderung sama, tekstur lembut dengan bau yang khas amis seperti bau telur. Hal tersebut disebabkan oleh bau dari bahan aktif AMSC-MP freeze dried. Perbedaan mendasar hanya terlihat pada warna sediaan dimana $F_{I}$ dan $F_{I I}$ yang tidak mengandung $H A$ tidak memiliki warna dan jernih transparan sedangkan $\mathrm{F}_{\mathrm{III}}$, $F_{I V}$ dan $F_{V}$ dengan peningkatan konsentrasi HA memberikan peningkatan warna yang menjadi lebih kuning hingga kuning kecoklatan yang disebabkan oleh warna dari HA. Hasil evaluasi organoleptis dapat dilihat pada Tabel 2. 
Tabel 2. Hasil pemeriksaan organoleptis sediaan gel AMSC-MP dengan beberapa variasi konsentrasi HA dengan

\begin{tabular}{ccccc}
\multicolumn{5}{c}{ kombinasi SPACE peptide $\mathrm{F}_{\mathrm{I}}, \mathrm{F}_{\mathrm{II}}, \mathrm{F}_{\mathrm{III}}, \mathrm{F}_{\mathrm{IV}}$ dan $\mathrm{F}_{\mathrm{V}}$} \\
\hline \multirow{2}{*}{ Formula } & \multicolumn{4}{c}{ Pemeriksaan Organoleptis } \\
\cline { 2 - 4 } & Warna & Bau & Konsistensi & Tekstur \\
\hline $\mathrm{F}_{\mathrm{I}}$ & Tidak Berwarna & Berbau amis seperti telur & Kental & Lembut \\
$\mathrm{F}_{\mathrm{II}}$ & Tidak Berwarna & Berbau amis seperti telur & Kental & Lembut \\
$\mathrm{F}_{\mathrm{III}}$ & Jernih kekuningan & Berbau amis seperti telur & Kental & Lembut \\
$\mathrm{F}_{\mathrm{IV}}$ & Kuning kecoklatan & Berbau amis seperti telur & Kental & Lembut \\
$\mathrm{F}_{\mathrm{V}}$ & Coklat kekuningan & Berbau amis seperti telur & Kental & Lembut \\
\hline
\end{tabular}

\section{Hasil uji pH}

Pengujian $\mathrm{pH}$ sediaan bertujuan untuk memenuhi kenyamanan dalam penggunaan secara topikal. Nilai $\mathrm{pH}$ gel yang baik adalah $\mathrm{pH}$ yang hampir sama atau berada pada rentang $\mathrm{pH}$ kulit yang berkisar antara 4,5 6,5. Apabila sediaan gel terlalu asam maka dapat menyebabkan iritasi, tetapi apabila $\mathrm{pH}$ gel terlalu basa maka kulit dapat menjadi kering dan bersisik (Tranggono, 2007).

Pengujian $\mathrm{pH}$ pada penelitian ini juga dilakukan untuk mengetahui apakah penambahan asam hialuronat yang dikombinasi dengan SPACE peptide memberikan pengaruh terhadap $\mathrm{pH}$ sediaan gel AMSC-MP. Basis sediaan gel yang telah dikembangkan berada pada rentang $\mathrm{pH} 5,1$ - 5,3. SPACE peptide memiliki $\mathrm{pH}$ sekitar 7,2 dan HA memiliki pH 4,5 - 8,5. Hasil uji diperoleh seluruh sediaan gel AMSC-MP berada pada isaran 5,37 - 5,26. Hasil analisis statistik menggunakan One Way Anova menunjukkan tidak ada perbedaan yang bermakna antara $\mathrm{pH}$ dalam setiap formula sediaan gel AMSC-MP $(\mathrm{P}>0,05)$ dan berada pada rentang $\mathrm{pH}$ kulit yaitu 4,5 - 6,5. Sehingga dapat disimpulkan bahwa peningkatan variasi konsentrasi asam hialuronat tidak mempengaruhi nilai $\mathrm{pH}$ sediaan gel AMSC-MP karena jumlah HA yang ditambahkan sangat sedikit $(0,01-0,04 \%)$. Nilai $\mathrm{pH}$ rata-rata pada beberapa formula sediaan gel AMSC-MP dapat dilihat pada Tabel 3 dan histogram Gambar 1.

Tabel 3. Hasil pemeriksaan nilai pH gel AMSC-MP dengan berbagai variasi konsentrasi HA dengan kombinasi SPACE peptide $\mathrm{F}_{\mathrm{I}}, \mathrm{F}_{\mathrm{II}}, \mathrm{F}_{\mathrm{III}}, \mathrm{F}_{\mathrm{IV}}$ dan $\mathrm{F}_{\mathrm{V}}$

\begin{tabular}{ccccc}
\hline \multirow{2}{*}{ Formula } & \multicolumn{3}{c}{ Replikasi } & \multirow{2}{*}{ Rata-rata \pm SD } \\
\cline { 2 - 4 } & I & II & III & \\
\hline $\mathrm{F}_{\mathrm{I}}$ & 5,37 & 5,36 & 5,32 & $5,37 \pm 0,03$ \\
$\mathrm{~F}_{\text {II }}$ & 5,34 & 5,33 & 5,35 & $5,34 \pm 0,01$ \\
$\mathrm{~F}_{\text {III }}$ & 5,29 & 5,34 & 5,30 & $5,31 \pm 0,03$ \\
$\mathrm{~F}_{\mathrm{IV}}$ & 5,30 & 5,32 & 5,29 & $5,30 \pm 0,02$ \\
$\mathrm{~F}_{\mathrm{V}}$ & 5,28 & 5,25 & 5,27 & $5,26 \pm 0,02$ \\
\hline
\end{tabular}

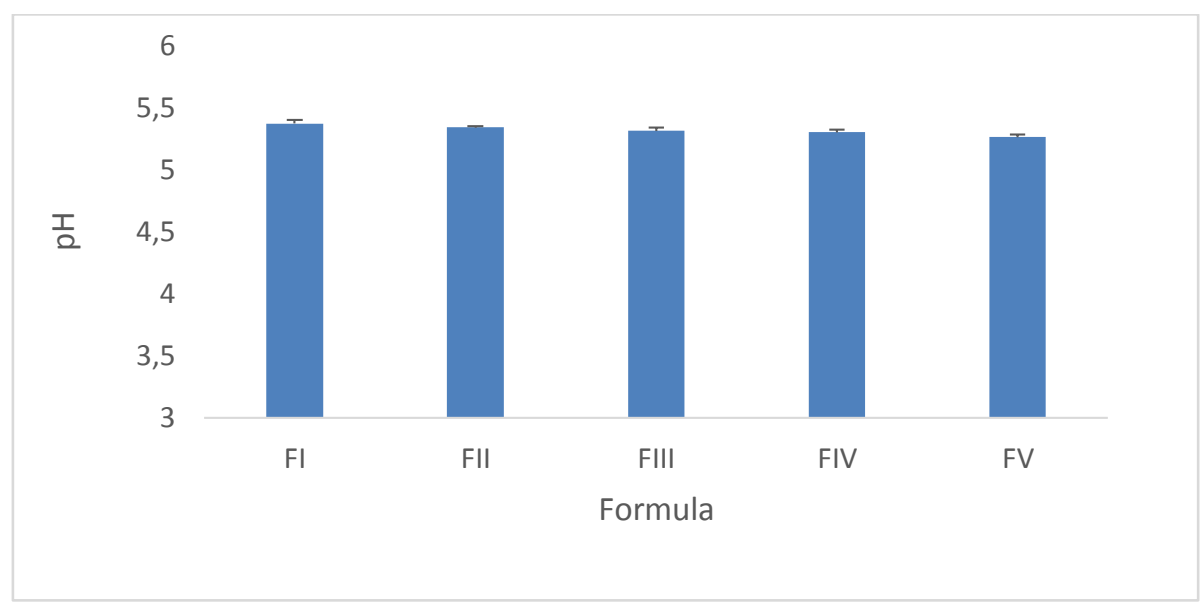

Gambar 1. Histogram hasil uji pH gel AMSC-MP dengan beberapa variasi konsentrasi HA dengan kombinasi SPACE peptide $\left(\mathrm{F}_{\mathrm{I}}, \mathrm{F}_{\mathrm{II}}, \mathrm{F}_{\mathrm{III}}, \mathrm{F}_{\mathrm{IV}}\right.$ dan $\left.\mathrm{F}_{\mathrm{V}}\right)$ 


\section{Hasil uji kapasitas penyebaran}

Suatu sediaan lebih disukai bila dapat menyebar dengan mudah dikulit. Pengujian kapasitas penyebaran sediaan dilakukan untuk mengetahui pengaruh HA yang dikombinasi SPACE peptide terhadap kemampuan menyebar sediaan gel AMSC-MP. Hasil uji kapasitas penyebaran pada beban konstan 25 gram diperoleh bahwa semakin tinggi konsentrasi HA, kapasitas penyebaran cenderung menurun dan berada pada kisaran nilai $6,50-6,13 \mathrm{~cm}$.

Namun hasil analisis statistik menggunakan one way anova menunjukkan bahwa tidak ada perbedaan yang signifikan $(\mathrm{P}>0.05)$ antara kapasitas penyebaran masing-masing formula sediaan gel AMSC-MP dan berada pada rentang yang diharapkan untuk sediaan topikal yaitu berkisar pada 5 - $7 \mathrm{~cm}$ (Garg dkk., 2002).

Pada Hasil tersebut, dapat disimpulkan bahwa peningkatan variasi konsentrasi HA tidak mempengaruhi kapasitas penyebaran gel AMSC-MP. Hal tersebut karena jumlah HA yang ditambahkan sangat sedikit $(0,01-0,04 \%)$. Hasil uji kapasitas penyebaran untuk masing-masing formula dapat dilihat pada Tabel 4 dan histogram Gambar 2.

Tabel 4. Hasil uji kapasitas penyebaran gel AMSC-MP dengan berbagai variasi konsentrasi HA dengan kombinasi

\begin{tabular}{ccccc}
\multicolumn{4}{c}{ SPACE peptide $\left(\mathrm{F}_{\mathrm{I},} \mathrm{F}_{\mathrm{II}}, \mathrm{F}_{\mathrm{III}}, \mathrm{F}_{\mathrm{IV}}\right.$ dan $\left.\mathrm{F}_{\mathrm{V}}\right)$} \\
\hline \multirow{2}{*}{ Formula } & \multicolumn{3}{c}{$\begin{array}{c}\text { Kapasitas Penyebaran }(\mathrm{cm}) \\
\text { Replikasi }\end{array}$} & Rata-rata $\pm \mathrm{SD}$ \\
\cline { 2 - 4 } & $\mathrm{I}$ & $\mathrm{II}$ & $\mathrm{III}$ & \\
\hline $\mathrm{F}_{\mathrm{I}}$ & 6,5 & 6,3 & 6,7 & $6,50 \pm 0,10$ \\
$\mathrm{~F}_{\mathrm{II}}$ & 6,6 & 6.2 & 6,4 & $6,40 \pm 0,20$ \\
$\mathrm{~F}_{\mathrm{III}}$ & 6,3 & 6,3 & 6,1 & $6,23 \pm 0,12$ \\
$\mathrm{~F}_{\mathrm{IV}}$ & 6,2 & 6,1 & 6,2 & $6,17 \pm 0,16$ \\
$\mathrm{~F}_{\mathrm{V}}$ & 6.1 & 6.1 & 6.2 & $6.13 \pm 0,06$ \\
\hline
\end{tabular}

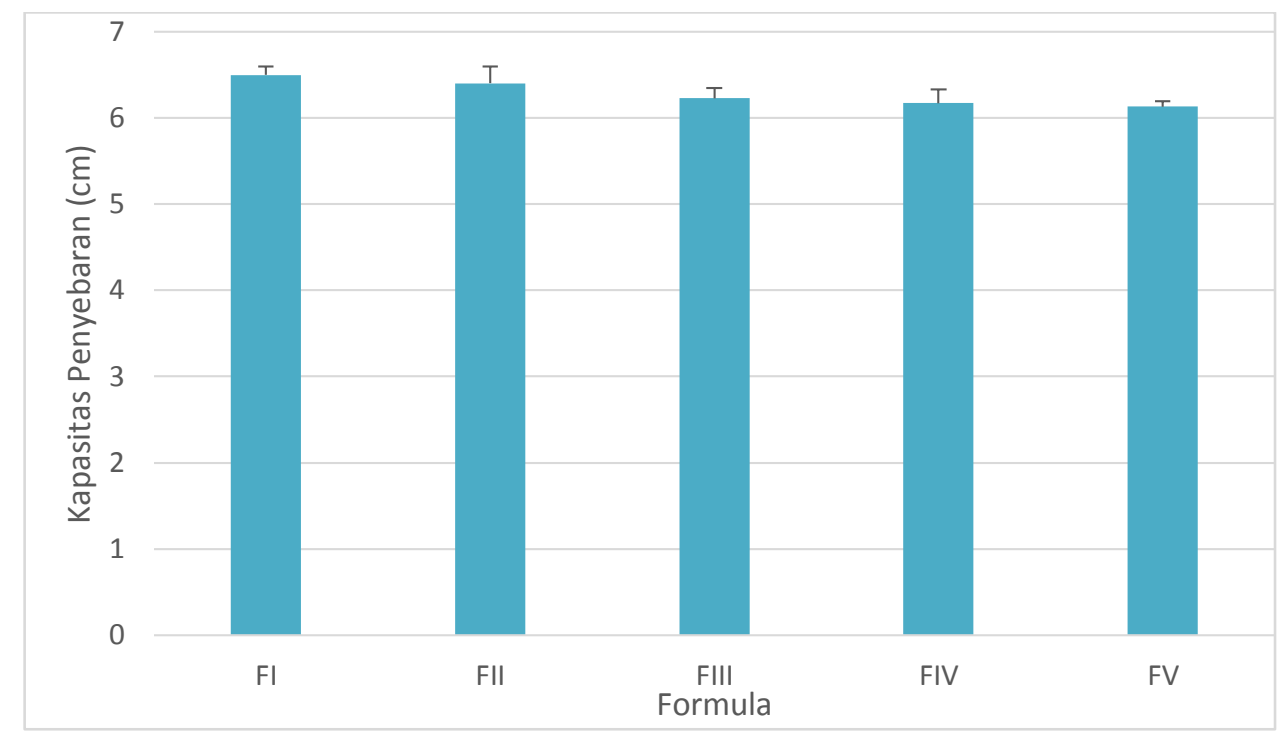

Gambar 2. Histogram hasil uji kapasitas penyebaran gel AMSC-MP dengan beberapa variasi konsentrasi HA yang dikombinasi SPACE peptide $\left(\mathrm{F}_{\mathrm{I}}, \mathrm{F}_{\mathrm{II}}, \mathrm{F}_{\mathrm{III}}, \mathrm{F}_{\mathrm{IV}}\right.$ dan $\left.\mathrm{F}_{\mathrm{V}}\right)$ pada hari ke 0,14 dan 28

\section{Stabilitas fisik sediaan gel AMSC-MP \\ Organoleptis pada penyimpanan 28 hari}

Sediaan farmasi dikatakan stabil apabila tidak ada perubahan dari karakteristik sediaan. Evaluasi stabilitas fisik sediaan gel AMSC-MP pada penyimpanan selama 28 hari yang dilakukan dengan mengamati perubahan organoleptis secara visual yang dilakukan pada hari ke0, ke-14 dan ke-28 didapatkan gel dengan konsistensi cenderung lebih kental dan meningkat pada hari ke-28. Hal ini dapat disebabkan karena adanya penguapan air selama proses penyimpanan. Untuk menghindari hal tersebut sebaiknya ditambahkan humektan (Rosita dkk., 2010).

\section{Stabilitas fisik pH sediaan}

Evaluasi stabilitas fisik sediaan gel AMSC-MP selama penyimpanan selama 28 hari dilakukan pengukuran $\mathrm{pH}$ pada hari ke-0, ke-14 dan ke-28.

Hasil pengujian nilai $\mathrm{pH}$ dengan metode statistika One Way Anova tidak menunjukkan adanya perbedaan yang signifikan ( $\mathrm{p}>0.05$ ) yang berarti bahwa 
penambahan HA yang dikombinasi dengan SPACE peptide tidak berpengaruh terhadap $\mathrm{pH}$ sediaan gel AMSC-MP dan stabil pada penyimpanan selama 28 hari. Nilai $\mathrm{pH}$ rata-rata pada beberapa formula sediaan gel AMSC-MP setelah penyimpanan selama 28 hari dapat dilihat pada Tabel 5 dan grafik pada Gambar 3.

Tabel 5. Hasil uji kapasitas penyebaran gel AMSC-MP dengan berbagai variasi konsentrasi HA yang dikombinasi SPACE peptide $\left(\mathrm{F}_{\mathrm{I}}, \mathrm{F}_{\mathrm{II}}, \mathrm{F}_{\mathrm{III}}, \mathrm{F}_{\mathrm{IV}}\right.$ dan $\left.\mathrm{F}_{\mathrm{V}}\right)$ selama penyimpaanan pada hari ke 0,14 dan 28

\begin{tabular}{cccccc}
\hline \multirow{2}{*}{ Formula } & \multirow{2}{*}{ Hari } & \multicolumn{3}{c}{ Replikasi } & \multirow{2}{*}{ Rata-rata \pm SD } \\
\cline { 3 - 4 } & & I & II & III & $5,35 \pm 0,03$ \\
FI & 0 & 5,37 & 5,36 & 5,32 & $5,32 \pm 0,01$ \\
& 14 & 5,31 & 5,33 & 5,33 & $5,29 \pm 0,02$ \\
\multirow{2}{*}{ FII } & 28 & 5,30 & 5,28 & 5,31 & $5,34 \pm 0,01$ \\
& 0 & 5,34 & 5,33 & 5,35 & $5,30 \pm 0,01$ \\
& 14 & 5,30 & 5,29 & 5,31 & $5,28 \pm 0,04$ \\
FIII & 28 & 5,32 & 5,27 & 5,25 & $5,31 \pm 0,03$ \\
& 0 & 5,29 & 5,34 & 5,30 & $5.28 \pm 0,02$ \\
& 14 & 5,27 & 5,29 & 5,30 & $5.26 \pm 0,02$ \\
FIV & 28 & 5,27 & 5,25 & 5,28 & $5,30 \pm 0,02$ \\
& 0 & 5,30 & 5,32 & 5,29 & $5,27 \pm 0,01$ \\
& 14 & 5,28 & 5,26 & 5,28 & $5,22 \pm 0,02$ \\
FV & 28 & 5,22 & 5,21 & 5,25 & $5.26 \pm 0,02$ \\
& 0 & 5,28 & 5,25 & 5,27 & $5,25 \pm 0,01$ \\
& 14 & 5,25 & 5,26 & 5,24 & $5,21 \pm 0,02$ \\
\hline
\end{tabular}

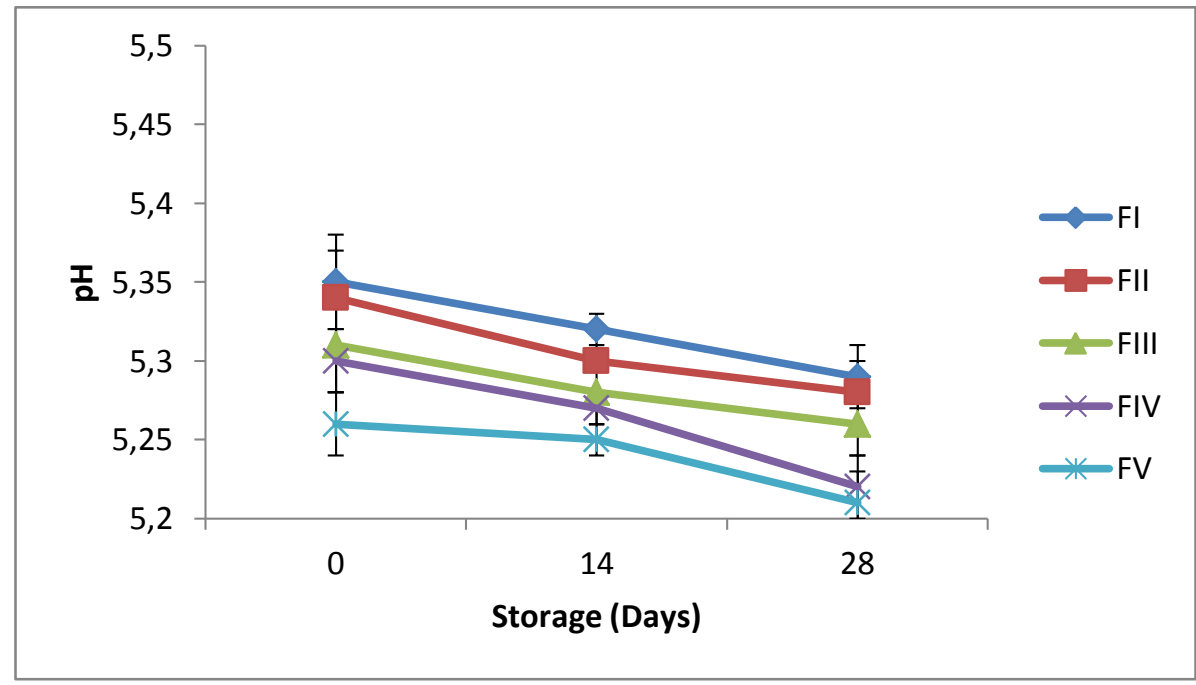

Gambar 3. Grafik hasil pengukuran pH sediaan gel AMSC-MP dengan beberapa variasi konsentrasi asam hialuronat yang dikombinasi SPACE peptide $\mathrm{F}_{\mathrm{I}}, \mathrm{F}_{\mathrm{II}}, \mathrm{F}_{\mathrm{III}}, \mathrm{F}_{\mathrm{IV}}$ dan $\mathrm{F}_{\mathrm{V}}$ pada hari ke 0,14 dan 28

\section{Hasil uji stabilitas kapasitas penyebaran gel AMSC-} MP

Kestabilan kapasitas penyebaran selama penyimpanan merupakan salah satu parameter akseptabilitas suatu sediaan (Martin dkk., 1993). Evaluasi pada penelitian ini untuk mengetahui apakah HA yang dikombinasi dengan SPACE peptide berpengaruh terhadap kapasitas penyebaran sediaan gel AMSC-MP pada penyimpanan selama 28 hari dan dilakukan pengukuran pada hari ke-0, hari ke-14 dan hari ke-28.
Dari hasil analisis statistik One way Anova, kapasitas penyebaran sediaan gel AMSC-MP pada masing-masing formula tidak menunjukkan adanya perbedaan yang signifikan $(\mathrm{P}>0.05)$. Hal tersebut menunjukkan bahwa penambahan HA yang dikombinasi SPACE peptide tidak mempengaruhi stabilitas kapasitas penyebaran gel AMSC-MP pada penyimpanan selama 28 hari. Hasil uji kapasitas penyebaran pada beberapa formula sediaan gel AMSCMP setelah penyimpanan selama 28 hari dapat dilihat pada Tabel 6 dan grafik pada Gambar 4. 
Tabel 6. Hasil pengukuran kapasitas penyebaran sediaan gel AMSC-MP dengan beberapa variasi konsentrasi HA yang dikombinasi SPACE peptide $\left(\mathrm{F}_{\mathrm{I}}, \mathrm{F}_{\mathrm{II}}, \mathrm{F}_{\mathrm{III}}, \mathrm{F}_{\mathrm{IV}}, \mathrm{F}_{\mathrm{V}}\right)$ pada hari ke 0,14 dan 28

\begin{tabular}{cccccc}
\hline \multirow{2}{*}{ Formula } & \multirow{2}{*}{ Hari } & \multicolumn{3}{c}{ Replikasi } & \multirow{2}{*}{ Rata-rata \pm SB } \\
\cline { 3 - 4 } & & I & II & III & \\
\hline I & 0 & 6,5 & 6,3 & 6,7 & $6,50 \pm 0,20$ \\
& 14 & 6,9 & 6,7 & 6,7 & $6,77 \pm 0,12$ \\
& 28 & 6,9 & 7,0 & 6,9 & $6,93 \pm 0,06$ \\
II & 0 & 6,6 & 6,2 & 6,4 & $6,40 \pm 0,20$ \\
& 14 & 6,6 & 6,5 & 6,6 & $6,57 \pm 0,06$ \\
& 28 & 6,7 & 6,7 & 6,8 & $6,73 \pm 0,06$ \\
III & 0 & 6,3 & 6,3 & 6,1 & $6,23 \pm 0,12$ \\
& 14 & 6,5 & 6,4 & 6,7 & $6,53 \pm 0,15$ \\
& 28 & 6,5 & 6,7 & 6,8 & $6,66 \pm 0,15$ \\
IV & 0 & 6,2 & 6,1 & 6,2 & $6,17 \pm 0,16$ \\
& 14 & 6,3 & 6,4 & 6,5 & $6,40 \pm 0,30$ \\
& 28 & 6,6 & 6,7 & 6,4 & $6,56 \pm 0,15$ \\
V & 0 & 6,1 & 6,1 & 6,2 & $6,13 \pm 0,06$ \\
& 14 & 6,3 & 6,4 & 6,2 & $6,30 \pm 0,10$ \\
& 28 & 6,5 & 6,3 & 6,5 & $6,43 \pm 0,12$ \\
\hline
\end{tabular}

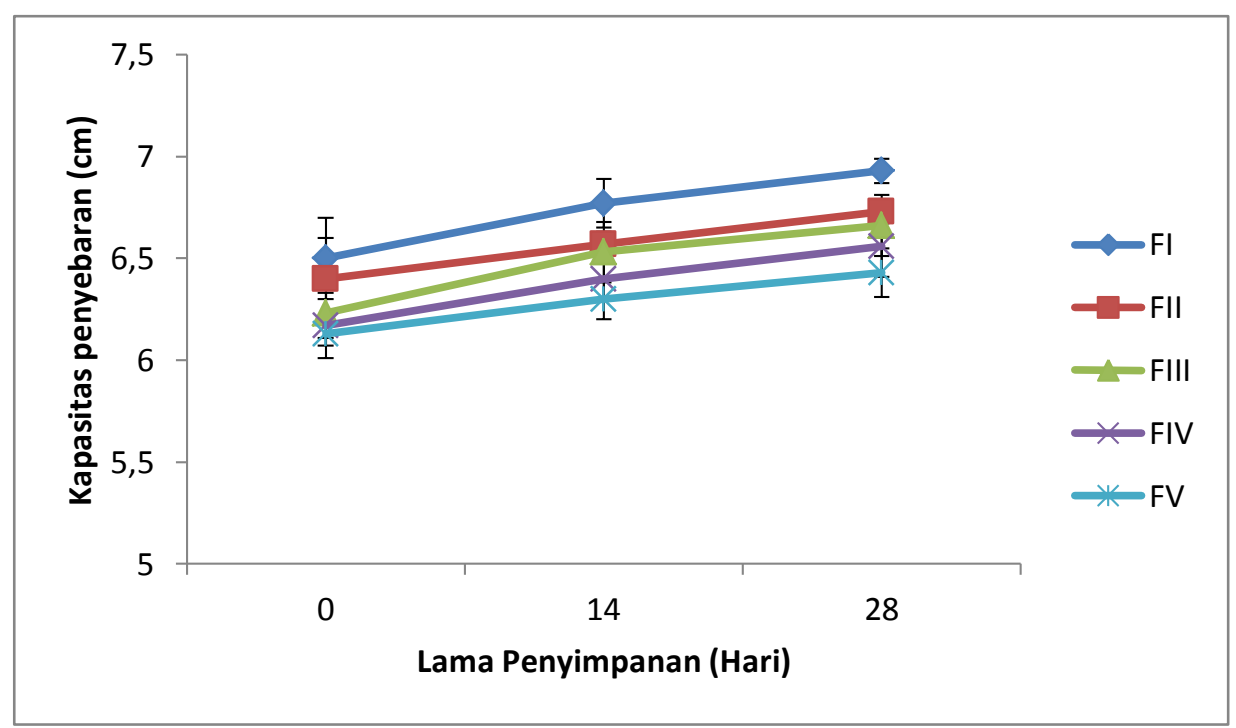

Gambar 4. Grafik hasil pengukuran kapasitas penyebaran sediaan gel AMSC-MP dengan beberapa variasi konsentrasi HA dengan kombinasi SPACE peptide $\mathrm{F}_{\mathrm{I}}, \mathrm{F}_{\mathrm{II}}, \mathrm{F}_{\mathrm{III}}, \mathrm{F}_{\mathrm{IV}}$ dan $\mathrm{F}_{\mathrm{V}}$ pada hari ke 0,14 dan 28

Perubahan $\mathrm{pH}$ sangat mempengaruhi stabilitas kimia bahan aktif dalam hal ini sitokin dan growth factor dan stabilitas fisik sediaan gel, menyebabkan perubahan karakteristik dan kapasitas penyebaran. Hasil pengujian ini diperoleh bahwa penambahan HA $(0,01$ - 0,04\%) yang dikombinasi dengan SPACE peptide tidak berpengaruh terhadap nilai $\mathrm{pH}$ sediaan sehingga diharapkan stabilitas bisa terjaga hal ini di dukung oleh tidak adanya perubahan kapasitas daya sebar sehingga sediaan gel tetap stabil.

\section{KESIMPULAN}

Penambahan HA (0,01 - 0,04\%) dengan kombinasi SPACE peptide tidak mempengaruhi karakteristik (organoleptis, $\mathrm{pH}$ dan kapasitas penyebaran) sediaan gel Amniotic Membran Stem Cell Metabolit Produk (AMSC-MP). Gel yang diperoleh memiliki warna yang jernih (transparan) hingga kuning kecoklatan dengan konsistensi kental dan berbau amis seperti telur dengan $\mathrm{pH}$ gel berkisar antara 5,26 - 5,37 dan diameter kapasitas penyebaran 6,13 - 6,50 cm masih berada pada rentang yang dipersyaratkan. Sediaan gel AMSC-MP dengan HA dan SPACE peptide stabil secara fisik ( $\mathrm{pH}$ dan kapasitas penyebaran) pada penyimpanan selama 28 hari. Perlu dilakukan penelitian lebih lanjut mengenai pengaruh penambahan $\mathrm{HA}$ dan SPACE peptide terhadap stabilitas kimia (penetapan kadar 
sitokin dan growth factor) pada sediaan gel freeze dried AMSC-MP.

\section{DAFTAR PUSTAKA}

Bos, J. D. \& Meinardi, M. (2000). The 500 Dalton Rule for the Skin Penetration and of Chemical Compounds and Drugs. Experimental Dermatology; 9; 165-169.

Chen, M., Vivek, G., Aaron, C., Anselmo, J. A. \& Muraski, S. M. (2013). Topical Delivery of Hyaluronic Acid into Skin Using SPACEPeptide Carriers. Journal of Controlled Release; 173; 67-74.

Chen, M., Zakrewsky, M., Gupta, V., Anselmo, A. C., Slee, D. H., Muraski, J. A. \& Mitragotri, S. (2014). Topical Delivery of siRNA into Skin Using SPACE-Peptide Carriers. Journal of Controlled Release; 179; 33-41.

Garg, A., Anggarwal, D. \& Sigla, A. (2002). Spreading of Semisolid Formulation: An Update. Pharmaceutical Technology North America; 2; 84-102.

Insausti, C. L., Blanquer, M., Bleda, P., Iniesta, P., Majado, M. J., Castellanos, G. \& Moraleda, J. M. (2010). The Amniotic Membrane as a Source of Stem Cells. Histology and Histopathology; 25; 91-98

Kumar, S., Zakrewsky, M., Chen, M., Menegatti, S., Muraski, J. A. \& Mitragotri, S. (2015). Peptides as Skin Penetration Enhancers: Mechanisms of action. Journal of Controlled Release; 199; 168-178.

Landau, M. \& Steven, F. (2015). Science of Hyaluronic Acid Beyond Filling: Fibroblasts and Their Response to the Extracellular Matrix. Plastic and Reconstructive Surgery; 136; 188S-195S.

Martin, A., Swarbick, J. \& Cammarata, A. (1993). Physical Pharmacy: Physical Chemical
Principles in the Pharmaceutical Sciences (3rd ed.). Philadelphia: Lea \& Febiger.

Meenakshi, G., Marek, D. \& Victoria, V. L. (2017). Mesenchymal Stem Cells from Adipose Tissue in Clinical Applications for Dermatological Indications and Skin Aging. International Journal of Molecular Sciences; 18; 208.

Mitragotri, S. \& Hsu, T. (2011). Delivery of siRNA and Other Macromolecules into Skin and Cells Using a Peptide Enhancer. Proceedings of the National Academy of Sciences; 108; 1581615821.

Murphy, S., Aleksander, S., Lujie, S. \& Khiry, S. R. H. (2017). Solubilized Amnion Membrane Hyaluronic Acid Hydrogel Accelerates FullThickness Wound Healing. Stem Cells Translational Medicine; 6; 2020-2032.

Pratiwi, F. D., Murtiastutik, D. \& Prakoeswa, C. R. S. (2018). Efek Pemberian Topikal Produk Metabolit Amniotic Membrane Stem Cell (PMAMSC) pada Penuaan Kulit. Berkala Ilmu Kesehatan Kulit dan Kelamin; 30; 95-101.

Rosita, N., Tutiek, P. \& Agustin. (2010). Stabilitas Fisik dan Efektivitas Sediaan Tabir Surya Kombinasi Oksibenson dan Oktil Metoksisinamat dalam Basis Gel Carbomer 940 dengan Penambahan Asam Glikolat. Majalah Ilmu Kefarmasian; 7; 16-26

Tranggono, L. (2007). Buku Pegangan Ilmu Pengetahuan Kosmetika. Jakarta: PT. Gramedia Pustaka Utama.

Witting, M., Alexander, B., Robert, B. \& Katerina, V. (2015). Interactions of Hyaluronic Acid with the Skin and Implications for the Dermal Delivery of Biomacromolecules. Molecular Pharmaceutics; 12; 1391-1401. 